Todd, J. \& Hibbert, D. (2017). Professional learning through a focus on task design: responding to historical scholarship and students' interests. Revista Electrónica Interuniversitaria de Formación del Profesorado, 20 (3), 15-31. DOI: http://dx.doi.org/10.6018/reifop.20.3.290951

\title{
Professional learning through a focus on task design: responding to historical scholarship and students' interests
}

\author{
Jason Todd ${ }^{(1)}$ and David Hibbert ${ }^{(2)}$ \\ University of Oxford ${ }^{(1)}$, Owen School, Oxford ${ }^{(2)}$
}

\section{Abstract}

This article reports on a small-scale collaborative research project that investigated the role played by scholarship and student interests in teachers' planning and professional learning. It involved three history teachers in different schools working either with each other and the researcher to plan tasks in the classroom, the project took place over the course of one year. A key conclusion is the need for dialogic spaces to allow teachers to explore and integrate ideas based on knowledge of their students, with knowledge from historical scholarship.

\section{Key words}

Knowledge; Planning; Teacher Development; Student interests.

\section{Aprendizaje profesional a través del diseño enfocado en tareas: dando respuesta a las investigaciones de referencia y los intereses de los estudiantes}

\section{Resumen}

Este artículo recoge los resultados de un proyecto colaborativo de investigación a pequeña escala que se ha encargado de investigar el rol que juegan las investigaciones de referencia y los intereses de los estudiantes en la planificación y aprendizaje profesional de los docentes. El estudio involucra a tres profesores de historia de diferentes escuelas que han trabajado tanto entre ellos como con el investigador con el fin de planificar tareas en la clase. Este proyecto se ha desarrollado en el tiempo de un año académico. Una conclusión clave es la necesidad de espacios dialógicos que permitan a los docentes explorar e integrar ideas basadas en el conocimiento de sus estudiantes, con conocimiento de las investigaciones de referencia.

\section{Contacto:}

Jason Todd. University of Oxford. jason.todd@education.ox.ac.uk 


\section{Palabras clave}

Conocimiento; Planificación; Desarrollo de los docentes; Intereses de los estudiantes.

\section{Introduction}

The publication, 'Designing tasks in secondary education' (Thompson, 2014), sought to "reprofessionalise teachers and question approaches to curriculum imposition" (p.3). In my chapter (Todd, 2014), I set out some issues and principles relating to the nature of task design in the history classroom. I argued that the Aristotelian concept of phronesis might serve to reconcile problematic epistemological binaries (Counsell, 2000) and help teachers negotiate complex processes involved in task design in a history classroom. Following Wineburg and Wilson's work ( 1991), phronesis might be seen as a process of pedagogical reasoning in which teachers turn inwards towards an examination of the nature of the subject, but in order to fashion this into a pedagogical form, Wineburg and Wilson also call on a turn outwards into the minds and settings of the learners in their classrooms.

Following this broadly theoretical modelling, a series of collaborations were planned with three local teachers looking to refine these principles and consider implications for practice. The collaborations had two principle aims.

- To investigate the sort of knowledge required and processes involved in planning for tasks in the history classroom.

- To collaborate and support the planning process, including knowledge exchange based on historical scholarship, research-informed knowledge of students and pedagogy and classroom-based action research.

A focus on the subject and the student are often the main motivations for teachers entering the profession (ATL, 2015). However, studies (Runte, 1998)_have suggested the proliferation of centralised high stakes examinations has eroded teacher agency with a focus on a narrowly proscribed set of outcomes (Biesta, 2004; Priestley, Edwards, Priestley \& Miller, 2012). In addition, recent shifts in England to a more 'rigorous' knowledge based form of testing has the potential of prompting teachers to focus on short-term knowledge acquisition to help students to pass tests; knowledge that is quickly forgotten (Stotesbury and Dorling, 2015). Finally Donaldson (2015, p.10), has argued that external drivers, such as examinations, potentially diminish teachers' "responsiveness to the needs of children and young people". Given that these factors have a potential negative bearing on teacher agency (and associated issues of retention), this paper seeks to explore the impact of trying to reconnect teachers with both subject and learner in a process of shared professional learning.

We begin by briefly outlining the challenges and principles of task design that acted as a starting point for this collaboration. Using transcripts from collaborative planning meetings and reflections from all the teachers involved, the paper then considers the types of knowledge that teachers drew on during their planning; in particular, the ways in which historical scholarship and students' interests impacted on their thinking. This is further exemplified by an account from one of the teachers involved in the project, written as a reflective story. 
The implications of these findings are explored; in particular, in thinking about the benefits of planning that is more responsive to students' interests and of the role of dialogue in supporting teachers' professional development.

\section{Phronesis: a tool for negotiating knowledge and acting ethically}

In the original task design article (Todd, 2014), I argued that reductive epistemological binaries can serve to distract teachers from consideration of the contexts of children's learning, including those contexts that existed outside of the classroom. I argue that these contexts are critically important in order to make history meaningful to young people and are underscored by the Schools' History Project's (SHP, n.d.) first principle: the 'determination to connect history to young people's lives'. Douglas Barnes (1976), adopting a constructivist approach to the curriculum, warned that a curriculum that begins with teacher's objectives rather than learners' understanding prioritises the needs of the curriculum over the needs of the learners.

I suggested that adopting an Aristotelian approach to knowledge can be helpful in reconciling these tensions. Aristotle made a distinction between three kinds of knowledge - episteme, techne and phronesis. The first two categories are well known in daily language as 'epistemological' and 'technical', while the word phronesis relates to a form of practical wisdom. Rather than a hierarchy of knowledge, the key to this conceptualisation is the interplay between these knowledge domains, with phronesis a tool to enable teachers to make judgements regarding the value and application of epistemological and technical knowledge.

Flyvbjerg (2001) explains the main differences between the three kinds of knowledge, highlighting how phronesis involves reasoning with regard to things that are good or bad for people. Phronesis, therefore, concerns values and goes beyond analytical, scientific knowledge (episteme) and technical knowledge or know-how (techne), involving 'the art of judgement'. In addition to highlighting a way of negotiating the knowledge derived from multiple sources phronesis, also implicates a critical ethical dimension that should be part of the teachers' planning. Phronesis emphasises practical knowledge and practical ethics; it is alert to context and implicates the teachers' intuition and experience, particularly in relation to what they know about the learners they teach. Phronesis is a deliberative reflective action. Moreover, it is best deployed in dialogue with other professionals and the learners themselves.

Following this, I argued that in order to plan effectively, teachers needed to draw on all the following domains:

- Knowledge of the subject: substantive knowledge combined with 'disciplinary' knowledge of how the subject works and the value and purpose of history.

- Knowledge of the students and different contexts of their learning.

- Knowledge of pedagogy - the strategies that can create an effective bridge between the two.

Each of these domains had a theoretical, technical and phronetic dimension. Figure 1, below, gives an indication of the ways this might work, while the suggestions in red highlight some of the potential inhibitors to this planning process. 


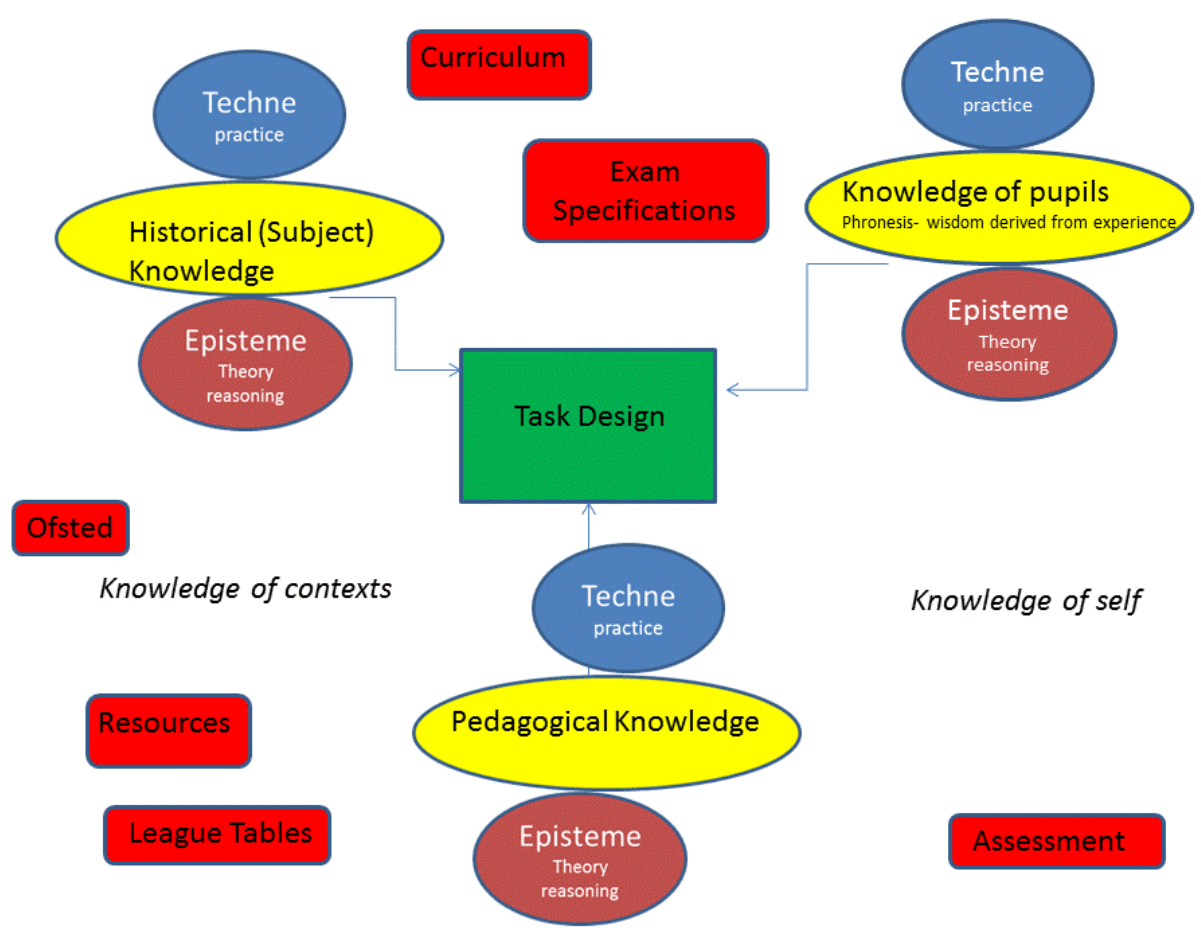

Figure 1: Task design in history epistemological domains.

One impact of these inhibitors might be to distort the influence of one domain on the planning process. For example, the way in which teaching to the test might serve to reduce the complexity at stake concerning historical knowledge to the regurgitation of facts; closing down discussion on the part of teachers and also students about the nature of historical knowledge and where the boundaries of the discipline lie.

In addition, Thompson argues that task design in the English classroom "often focuses on the teacher's objectives for task completion produced under the pressure of performativity, rather than the developmental demand of learners" (Thompson, 2014, p.88). In this way, knowledge of the students is potentially side-lined: this knowledge might include not just their developmental starting points or preconceptions but also affective needs and desires (Barton, 2009). This performativity combined with contextual pressures on time might also serve to limit engagement with new historical scholarship.

At a meeting with the teachers in February 2015, following a reading of the task design chapter, we discussed the model outlined in Figure 1 and agreed on the following key principles for planning in history:

- Complexity - an emphasis on the contingent in the context of enquiry and the use of evidence

- The centrality of the enquiry question

- The centrality of the students - their affective needs, values and prior knowledge. 
- The need to give students access to broader cultural enterprises that, in turn, enable thought about the boundaries of the discipline and engagement with controversy and debate.

We discussed potential ways of developing these principles into practice related to two classroom-based projects; one focussed on the First World War the other the Holocaust. Underpinning planning and practice would be a commitment to dialogue. Writers like Hattie (2012) have suggested that creating spaces where teachers talk about practice can have a powerful impact on their development and also on student achievement. A small scale research project was set up aiming to evaluate how using the principles and collaboration in planning might enable a better integration of the different sources of knowing outline in figure 1.

\section{Outcomes of the collaborative project}

In order to build knowledge of the students, a preliminary investigation, using questionnaires and focus group sessions, was undertaken exploring student motivations and desires in relation to history generally and to the specific topics on which each teacher wanted to focus. The outcomes of this preliminary investigation established student perspectives, including their dispositions towards and prior knowledge, of the topics they will be studying. This allowed for collaborative planning (with teachers and researchers) of an intervention that takes account of those starting points and that is responsive to the specific contexts/priorities presented at each school.

Following this, I met with the individual teachers to discuss the outcomes of this preliminary research and also to share relevant pedagogical and historical knowledge. We worked collaboratively, drawing on the three domains and principles to plan a sequence of lessons.

The rest of this article will focus mainly on the collaboration with one of these schools, Owen School, a culturally diverse establishment with a high proportion of BAME students. The teacher David is in his $3^{\text {rd }}$ year of teaching: he trained on the PGCE course at Oxford and is currently a school-based mentor with the PGCE course. We met on 3 occasions to plan the tasks in the enquiry (only one, formally) and below he outlines his thoughts about the impact the collaboration has had on his own professional development and particularly his approach to planning.

I worked with David to administer a quiz/questionnaire about the First World War, conduct a group-planning task and to give suggestion cards asking students to consider what historical topics they thought they should study next. In addition, David undertook some $6^{\text {th }}$ form ${ }^{1}$ reflection questions about diversity in the curriculum. Based on this investigation the focus at Owen School was to develop a classroom-based intervention that is more attentive to the diverse nature of the students in a Year $8^{2}$ class on the topic of the First World War.

The rest of the section will outline the outcomes of collaborations using the transcripts from the formal planning and debriefing sessions. David's formal planning meeting took place on the $5^{\text {th }}$ May 2016. The meeting with the other teachers, F1 and F2, took place on $23^{\text {rd }}$ May. A followup meeting involving all parties took place on the $19^{\text {th }}$ July. I attended all meetings (JT in the

\footnotetext{
${ }^{1}$ 16-18 years, studying advanced level History

${ }^{2}$ Year $8,12-13$ years, usually $2^{\text {nd }}$ year of senior school
} 
transcripts). The transcripts from the planning meetings were initially coded using 2 key questions:

1. What sort of knowledge do teachers draw on during planning?

2. What stimulates a great idea or causes teachers to change their mind during planning?

In an analysis of the recorded planning sessions, all forms of knowledge in Figure 1 (above) were represented. While the transcripts reveal a number of things that served to drive the professional dialogue forward. Some of this related to a discussion about the use of language explicitly in relation to framing the enquiry question. However, another common feature was the way the teachers often used questions. Nevertheless, it was evident there was considerably more focus on knowledge of the students in planning. This echoes Burn, Hagger, Mutton and Everton (2003), who found that a very high regard for students' learning featured in their analysis of the reasons offered by student teachers for their teaching decisions. Therefore, a second sweep of coding, using the typography from Burn et al., was applied to the transcripts.

1. Concern with pupil knowledge

2. Concern with pupils' action/behaviour (e.g. paying attention in class)

3. Concern with pupils' affective state (e.g. enthusiasm, confidence, motivation)

4. Concern with pupils' ability (e.g. higher attainers, students with learning difficulties)

5. Concern with pupil progress/achievement

a. Cognitive process/development (e.g. acquiring new concept/skill)

b. Creation of product (wall display, performance)

c. Coverage (pupils getting through the work)

6. Concern with self (i.e. self-learning)

7. Concern with lesson content and continuity (e.g. each lesson follows from previous and content covered is broad enough)

Codes 1 to 4 (in the white box) are adapted from Table 1 (p. 319) and are concerned with student factors. I also chose to include the codes numbered 5 to 7 , which are discussed in the Burn et al.'s (2003) article and apply to the interviews.

Figure 2: Coding of May planning transcripts

\section{General Findings}

In the planning sessions, teachers were concerned with the content of each lesson including a desire to reflect recent historical scholarship, as well as how it tied into the next (concern with lesson content and continuity). The teachers also discussed students' existing knowledge, including the preliminary research, and their ability. There was also some concern around students' affective state (e.g. teachers were trying to predict how students might react to certain aspects of the lesson). In the planning conversations, there was less concern about selflearning, pupil progress and acquired knowledge. These concerns were more prevalent in the debriefing conversations. 


\section{Concern with pupil knowledge}

A considerable amount of time during the planning sessions was allotted to discussing pupils' existing knowledge. The teachers were highly aware of topics students had covered and might bring with them to the lesson. One example is given below:

F2: ... we decided to do a few lessons of context... we didn't want to start with: Hitler came to power, and not really understanding why... We looked at establishing a dictatorship, and controlling opposition... looked a little bit at men, women and children in Nazi Germany.

F1: Yeah... the lesson we did today is beginning to look at the growing persecution of Jews in the 1930 s... but they're not going to look at that in a lot of detail, and I don't think they will understand that long-term history of anti-Semitism, and it not being a German idea... and I think... I worry that, perhaps, that is their thinking at the moment.

23.5.16 KADGS Planning. $1 \mathrm{hr} 13 \mathrm{~min}$

The weight of these discussions related to the substantive knowledge students might have, however this was based on coverage in school not whether the students had understood it, or sources of knowing beyond school. At some points, teachers did consider the potential disciplinary knowledge students would acquire throughout the planned unit. Instead of being concerned with what pupils already knew, this teacher tried to envision what type of knowledge/skills the students would end up with:

F1: But is that really what we want the students to be able to do? ... To be able to talk about the Holocaust as a case study of anti-Semitism... I think it kind of is, but I think we need something about change and continuity....

\subsubsection{KADGS Planning (2). $1 \mathrm{hr} 34$}

They also considered the outcome of a certain question, rather than being concerned with whether or not the students can comprehend it, based on their previous knowledge:

DAVID: I think the point of this question isn't understanding - it's to provoke thinking ... this isn't a sort of testing question.

\subsubsection{DAVID \& JT Planning. 1 hr 33}

The above illustrates the teachers' continual reflection on the purpose of what they are teaching. This, therefore, goes beyond the concern for "pupils' acquired knowledge", and could perhaps better be categorised under "pupils' progress/development" (see section 5 below), indicating a degree of overlap between categories.

Another feature in these planning sessions was thinking about pupil misconceptions.

F1: Yeah... the lesson we did today is beginning to look at the growing persecution of Jews in the 1930 s... but they're not going to look at that in a lot of detail, and I don't think they will understand that long-term history of anti-Semitism, and it not being a German idea... and I think... I worry that perhaps, that is their thinking at the moment.

23.5.16 KADGS Planning (2). $1 \mathrm{hr} 34$ 
A reflection also stimulated by looking at findings from a report (Foster et al., 2016) highlighting student lack of understanding of anti-Semitism.

\section{Concern with pupils' action/behaviour}

There was little concern with pupils' action and behaviour in planning conversations. Rather, teachers were concerned with pupils' (emotional) reaction to the lesson.

\section{Concern with pupils' affective state}

In the planning interviews, teachers often raised concerns about how students might react to the lesson, the use of certain words, etc. They were also constantly questioning whether their students would find the lesson engaging, motivating and interesting, or whether the difficulty level might make some students feel frustrated. The preliminary research that David and I conducted with his year 8 class and his $6^{\text {th }}$ formers serves to highlight a particular desire for relevance.

DAVID: Yeah. ... "I think what we're talking about in terms of engagement, it's useful to start with the relevant stuff first, and then come back to the goals of the project." ... and then we go to, we got the diagram, then the basic breakdown of the goals. First we have to make sure they understand the meaning of each of these three things" (Race, Gender and Class)

\subsubsection{DAVID \& JT Planning. $1 \mathrm{hr} 33$}

DAVID: ... then [I will ask students: write] a short paragraph describing yourself. What are the things that define you? But here I took the class a bit out... an issue with personal judgement that could stop them from engaging at all... maybe that's wrong.

\subsubsection{DAVID \& JT Planning. $1 \mathrm{hr} 33$}

David also expressed a strong desire to engage students throughout the lesson and to make students feel ownership towards their own learning.

DAVID: ... the core message being, it's about them, we are interested in what you have to say, we've created this in response to what you told us... we really kind of are trying to help you see why history is important."

\subsubsection{DAVID \& JT Planning. $1 \mathrm{hr} 33$}

\section{Concern with pupils' ability ${ }^{3}$}

Compared to affective needs, teachers were less directly concerned with the ability of their students. The concerns that did arise were around (1) mixing students of different abilities in order to encourage learning, (2) excitement around helping students with previous concentration/behavioural challenges, and (3) how to ensure low ability students could contribute.

\footnotetext{
${ }^{3}$ The use of 'ability' follows the coding in the original article(Burn et al., 2003), it is recognised it is a problematic and contested term.
} 


\section{Concern with pupils' progress/achievement}

In Burn et al.'s (2003) article, this concern is divided into three sub-categories: (a) concern for cognitive development; (b) concern for creation of product (e.g. a poster); and (c) concern for coverage (i.e. getting through the syllabus).

The teachers were notably less concerned with covering the syllabus or even the lessons they had designed. While some were concerned with the creation of a product (timeline, shading activity, etc.) during the planning stage, this did not seem to be a major concern in general. Instead, most of the conversation around pupils' progress/achievement was around students' progress in terms of cognitive development. Teachers seemed concerned with making students think, not just follow instructions. They also reflected on the purpose of the unit (social moral learning, critical thinking, historical knowledge, etc.)

DAVID: ... because of the nature of GCSE, I think it is progress if the student recognises that ...this answer is not necessarily correct, they disagree for different reason... she doesn't have to pick.

\section{Task design debriefing.}

DAVID: And they like being pushed, but I think the real tension with complexity, is pushing them, without drowning them... while still making them feel they are safe... I was talking to a few of the students at the end of this... saying what do you think of this? And one of them was saying it really made them think, the implication being, they're not made to think very often.

Task design debriefing.

These concerns with the progress of students were more generally articulated in the debriefing sessions.

\section{Concern with Self}

Teachers discussed what they found most helpful, what turned out to work best and also reflected on lessons learned through this most recent teaching experience during the debriefing session in July.

Some of the "lessons learned" by teachers concerned specific teaching techniques, such as returning to a question or activity at regular intervals.

F1: I think one of the "helps" that I found particularly helpful was constantly revisiting the same activity or content, or anything. I mean, on a practical level, it meant that resourcing it was much easier, same timeline, things like that... It also did mean that if a student missed one lesson, it wouldn't necessarily matter as much... but also one of the reasons why I revisited it so much, I wanted the girls to realise, when they had changed their mind, and... kind of think: why have I changed it?

Task design debriefing.

Other "lessons learned" had less to do with specific approaches in the classroom and more to do with general attitudes toward the teaching profession.

F1: ... for me, one of the things I was struggling with, was picturing it at their level... even in that class, there are some very mature students, compared to 
some very very silly students... there are some that cry very easily, I just I didn't know what their reaction would be. ... Equally, I didn't know...I think I underestimated how far I can push them...

Task design debriefing.

DAVID: Something I thought was quite interesting in terms of complexity was... how tempting it is to push them to where you want them to go... I think if we really are asking them to think in complex ways, I'm getting more and more convinced that's really unhelpful... I think that GCSE and A' level work in the same way as an incentive... to get them to a place where both you and they feel like it's OK. I feel like we need to build in more time in wrestling. ... So much of the value is in the tension and the complexity.... .If you're introducing that...giving them time to really process it.

Task design debriefing.

\section{Concern with lesson content and continuity}

During the planning stage, most of the teachers' concerns revolved around content and continuity between lessons. There were many instances where teachers helped each other "finely tune" their unit so that there was a clear continuity between lessons. Often, one teacher would voice his/her concerns around their own lesson and the colleague(s) would try to come up with ways to improve a lesson to ensure pupil comprehension.

\section{Synopsis}

A key principle used to reconcile different concerns was the discussion about the articulating of the enquiry question, it was clear that the dialogue here enabled teachers to play with the questions as a way of reconciling key concerns such as 3) concern with pupils affective state and 7) content, especially recent sch.

David's original enquiry, with a significance focus, had been "What have we forgotten about World War one?" The preliminary investigation of David's students understanding of the First World War had highlighted their limited sense of the global reach of the war but also their affective desires for a more diverse curriculum, one that might be more relevant to their world. Following this I introduced David to recent scholarship on the First World War particular Reynolds book The long shadow ( 2013). Therefore when we met in May David had begun to frame a question about the shadow the war cast, arriving at "How far does the First World war cast a shadow on the world I live in?'. The question helped reflect the range of concerns raised in planning and aligned the study with a conceptual focus on both diversity, through looking at gender, race and class and change and continuity.

The initial discussions with the teachers focused on the range of knowledge sources needed to plan effectively for the history classroom and culminated on the drawing up of a set of guiding principles outlined on page 5 above. While the last principle featured only in a limited way in planning discussions, the other three were clearly evident. It is possible to argue that the foregrounding of the first three principles also served to overcome some aspects of teachers' concern with self and particularly, concern with pupils' ability. 


\section{Personal reflections by a classroom teacher}

\section{The value of student perspectives}

One of the most powerful insights created by this process was how the experience of engaging with the perspectives of my students acted as a driver for academic rigour. As a teacher engaged in contemporary educational discourse, particularly through social media, I have become increasingly used to seeing engagement and a student-centred approach being portrayed as antithetical to high academic standards. This portrayal is generally made by teachers and writers who self-identify as 'traditionalist'. What this process revealed to me is that this is very much a false dichotomy. The importance of tending explicitly to student knowledge and placing a premium on the nature of the subject being taught is inarguable. However, explicitly attending to the way that students perceive the subject and the perceptions that they bring to the classroom should equally inform decisions on what is taught and how. This is not pandering: it is a vital part of reconciling the tensions that are inherent in teaching practice. To fail to attend to this and to see students merely as uncomprehending novices is to miss a vital aspect of the communicative act of teaching. If effective task design is truly to be achieved then professional knowledge, subject knowledge and knowledge of the students must be in dialogue with each other. This is where phronesis, in terms of collaboration, can play a key facilitator role. To exclude or reduce the importance of any of these three strands is to close a vital avenue of knowledge. Fully developed pedagogical and curricular decisions require the reconciling of the tensions between these strands, as well as consideration of the interactions between them. With too much emphasis on substantive knowledge and a lack of emphasis on the agency and uniqueness of the learner, teaching risks becoming a process of imposition which is disconnected from the perspective of those for whom the process is theoretically created. For some of my students (many of whom were already hard-working and engaged), this sense of connection seemed to stimulate an additional layer of intellectual curiosity and to motivate them to actively seek complexity in a new way. This was also true with the explicit value that we placed on diversity in this enquiry; something that all of the students understood was a response to their perspectives. A striking example of this was a conversation that I had with a male student during the course of the first lesson of the enquiry; one in which the perceptions and hopes of the students are specifically sought. During the conversation, this student came to the realisation that his aspirations of becoming a doctor would probably not have been available to someone of his ethnic background in the $19^{\text {th }}$ century. His pause and shock during this moment was striking. I suspect that this young man already understood this on an intellectual level. What gave this realisation such power for him was the relationship to his own human experience. The value of seeking additional knowledge of our students therefore lies also in the sense of connection and participation that is created in them, as well as providing teachers with information that aids the planning process.

\section{My perspective being challenged}

A central outcome of this process was an emphasis on the enabling power of collaboration between professionals, between teachers and academics, as well as partnership between students and teachers. My experience of this collaboration was primarily one of having my thinking and approaches challenged. This was initially true in relation to the research that was carried out with my $Y 8$ students; their perception of history, of their lessons and of the world around them was surprising and challenging in a way that forced me to look again at my 
planning. The same was also true of the planning meetings with other teachers involved in the project and my meetings with Jason.

As evidenced in some of the extracts from our meetings, Jason continuously challenged me to justify my thinking and to sharpen my approach. This was given an even greater value by the range of subject knowledge and knowledge of scholarship on the First World War that Jason brought to the discussions. Jason introduced me to the work of David Reynolds (2013) and a change in emphasis away from the traditional approach to the First World War and towards one which focuses on the global reach and consequences of the conflict. This initial exchange took place in a pub and continued throughout the meetings and planning process, in both formal and informal contexts. This combination of pedagogical challenge and a wider knowledge base, coupled with my knowledge of my students, resulted in many breakthroughs and important alterations to the enquiry that would later pay rich dividends in the classroom.

What was perhaps most striking is the way that this experience clashed with the experience of being a practicing teacher. The ever increasing administrative and time demands of a classroom teacher mean that the time for this kind of challenge and rethinking is scarce. This results in an environment in which the first pedagogical or curricular decision taken is often the sole decision. This can mean that I become uncritical and conservative in the decisions I make. During this project, I was struck by how novel it was to be given the time to discuss these issues in an extended way and, by contrast, how unreflective many of my planning decisions often are. This perception was reemphasised by another teacher's description of the weekly, timetabled planning time that she enjoyed at her school. In consideration of my own experience, coupled with conversations with many of my contemporaries and more senior colleagues, it is evident that these constraints and the resultant lack of a sense of meaningful professional engagement is a driver of the disillusionment and frustration that is being experienced by many in the profession. It therefore has important implications for teacher morale as well as teacher retention. It is crucial that what might be called 'phronetic spaces' are created in which this collaboration between teachers is given the time and emphasis that it needs in order to have a real impact. Equally, the creation of these spaces can be aided by teacher engagement with and response to the perspectives of their students. Both of these processes can perhaps help to address some of the problems facing the profession today.

\section{Discussion}

Although this study is exploratory and descriptive in nature, its findings provide useful suggestions for practitioners in schools and have relevance for ITE policy. The starting point for this exploration was that history teachers need to draw on a range of different knowledge sources in order to be able to plan effectively. This includes knowledge of the students, the subject and of pedagogy. The nature of this knowledge is both generalisable and practical episteme and techne. The article assumes that planning is a complex intellectual process involving an often difficult set of reconciliations between different sources of knowledge, frequently inhibited by a range of external factors. We argue that this decision-making process, at the heart of lesson planning, includes a strong ethical dimension. This series of reconciliations, with this ethical undertow, implicates Aristotle's 3rd dimension of knowledgephronesis. This form of knowledge is deliberative in that it requires a regard for what is good. I would argue that this is best realised through collaboration and dialogue. 
In the context of ITE, this deliberative and collaborative reflection has a value in relation to persistent concerns regarding the relationship of theory and practice, with evidence suggesting the difficulty novice teachers experience in applying theory to practice (Mclntyre, 1993). One key explanation for the failure of the 'application model' is in relation to the heterogeneous nature of the learner: "What works in one situation with one group, does not automatically work in another situation or with another group" (Lunenberg \& Korthagen, 2009, p228). The perceived failure of application has led to the development of more schoolbased teacher education. However, the development of phronesis is not solved by simply replacing theory with more experience, particularly if consideration is given to the ways in which schools contexts might encourage narrowly reductive approaches related to measures of performativity (Sachs, 2016). One of David's key reflections concerned the ways in which his discussion with others outside the school enabled his perspective to be challenged.

The deliberative and collaborative nature of the reflection argued here is more in line with McIntyre's idea of practical theorising (McIntyre, 1993). He suggested that reflection was especially difficult for the novice teacher with limited experience. Instead, Mclntyre suggests the need for a "process of experimentation and falsification" coupled with a "commitment to making available to our students theoretical knowledge which they will mostly, with refinement, be able to usefully assimilate to their professional thinking" (p.41). Mclntyre's theorising, echoing Aristotle, offers both technical and practical dimensions but he also makes a case for emancipatory theorising that involves thinking about wider ethical issues regarding the purpose and nature of what we are doing in the classroom and the ideological contexts in which that work takes place. This theorising is emancipatory because "Reflection concerns one's present practices, but theorising concerns the whole world of possibilities for the future." (p.47)

This study highlighted two critical dimensions that enabled the drawing together of experience, theory and practical wisdom: firstly, the scope to talk about the interaction between theory and practice. "Reflection seems the vital instrument for making the connections between experience, theory, and practical wisdom" (Lunenberg \& Korthagen, 2009, 235). The project sought to create dialogic spaces that enabled collaboration and professional development, such that theory became theorising, related to context. What was clear from David's reflections and the transcripts is that the approach, underpinned by the guiding principles, served to challenge current approaches to planning and as such, served as a model of professional development. This has implications for teacher educators, mentors, and school managers, too. In order to better support this theorising, it is critical that those involved in teacher education articulate our own theorising, including the pedagogical warrant for what we do and the ethical standpoint underlining it.

The second key dimension was the foregrounding of the student both in the principles and also in the course of undertaking specific research into their affective needs and desires. Figure 3, below, summarises some of the key outcomes from Owen School regarding students' knowledge, based on small scale study, the subject especially Reynolds (2013) and pedagogy that informed the planning. In this case, a synergy existed between what was known about the students' desires regarding the global nature of the First World War and the historians' (Reynolds, 2013) call for a broader engagement with the topic. 


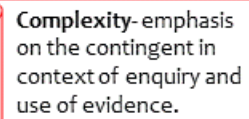

David Reynolds (2013) Lost touch with FWW Global nature Consequences/shadow

Bellinger (2008)-personal stories. Continuity and change (Counsell)

\section{Owen School}

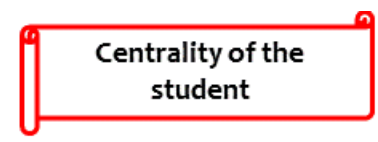

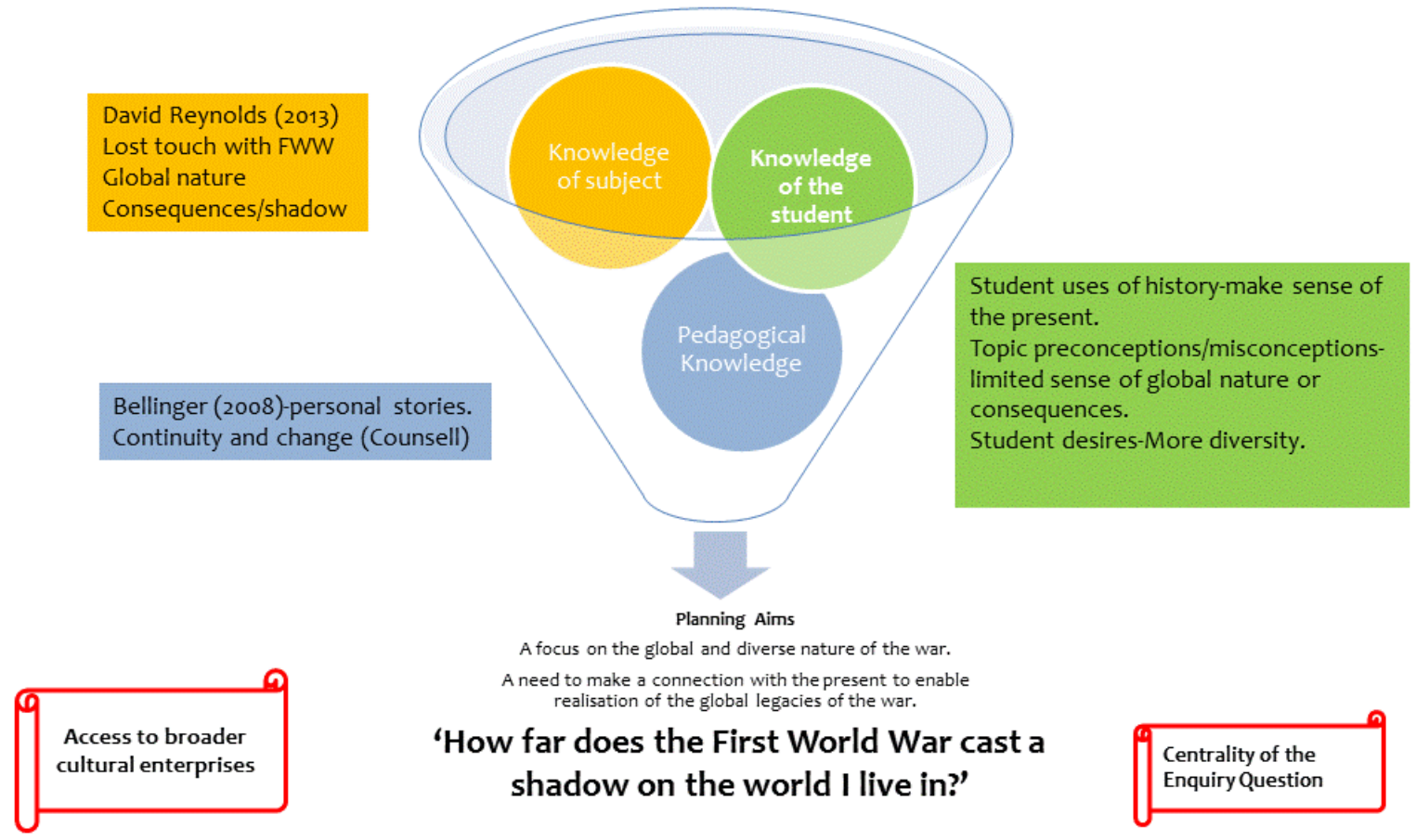

Figure 3. Summary of Owen School

What the diagram does not show is the processes involved in arriving at this planning approach and the impact on the teachers' professional learning. A particularly important dimension of this process was reconciling what was known about the students with what was known about the subject. In this particular case, both students and the scholarship seemed to be demanding the telling of a more complex story of the First World War. This shared desire for complexity, underpinned by the centrality of the student, offered scope for the development of a more relevant curriculum without losing any of the analytical rigour. In particular, typical teacher concerns, often related to the external accountability, were perhaps challenged by the focus on complexity and also ameliorated by a greater emphasis being placed on the students from the onset, such that the complexity was therefore embedded in students' needs and desires. The collaboration might have also served to enable greater risktaking on the part of the teachers (Ciampa \& Gallagher, 2016) or experimentation (McIntyre, 1993).

The dialogue between the teachers and the researcher enabled the building of bridges between what is known about the topic and what was known about the students. Many of the discussions included the sharing of pedagogical strategies to enable students to access the complexity at the heart of planning, such as the use of personal stories (Bellinger, 2008) or thinking about approaches to teaching change and continuity (Counsell, 2008). Many of the conversations concerned the focus of the conceptual underpinning of the enquiry; for David, 
the balance between change and continuity and similarity and difference. This was developed in the ways in which teachers drew on their own experiences, reading and resources, particularly with the two schools that shared a focus on the Holocaust. Using broader research based knowledge (Foster et al., 2016), in conjunction with their own classroom based investigation, led to a particular focus on anti-Semitism. The conceptual focus on change and continuity served the demands of a GCSE curriculum, while engagement with historical scholarship (Berger, 1986; Cesarani, 2016) informed the discussion about how to frame the enquiry.

The final set of implications relates to practitioners in schools. David expressed jealous respect for another colleague involved in the project, whose school had allocated regular planning time along department lines; something his Head of Department would welcome. This structural commitment, to give time to teachers to plan collaboratively, is vital in enabling ongoing professional development. However, time is not the only factor at play here: our project benefitted from a clear sense of distributed expertise and the explicit articulation of principles. The recognition of this expertise was vital, especially the ways in which working with others beyond one's context can serve to challenge habituated practice. De Neve and Devos's work on professional learning communities (De Neve \& Devos, 2016) also highlights the importance of cultural school conditions. The development of trust within our meetings can be ascribed to the history shared with all the participants (all the teachers having been interns in different years at the Education department) and this certainly helped in giving access to a shared language and approach. The trust was also based on a shared commitment to placing the students at the centre of our planning. It is here that the final value of phronesis resides, transcending a narrow instrumentalist idea of teacher professionalism and enabling a more expansive ethical theory that is "inseparable from the wider moral values and virtues of education" (Carr 2006, p182).

\section{References}

ATL. (2015). New teachers already demotivated about teaching at the start of their careers. Retrieved from https://www.atl.org.uk/latest/press-release/new-teachers-alreadydemotivated-about-teaching-start-their-careers

Barnes, D. R. (1976). From communication to curriculum. Harmondsworth: Penguin Books.

Barton, K. C. (2009). The Denial of Desire: How to Make History Education Meaningless. In National History Standards: The Problem of the Canon and the Future of History Teaching (pp. 265-282). Information Age Pub.

Bellinger, L. (2008). Cultivating curiosity about complexity: What happens when Year 12 start to read Orlando Figes' The Whisperers? Teaching History, (132), 5-14.

Berger, D. (1986). History and hate: the dimensions of anti-Semitism. Philadelphia: Jewish Publication Society.

Biesta, G. J. J. (2004). Education, Accountability, and the Ethical Demand: Can the Democratic Potential of Accountability Be Regained? Educational Theory, 54(3), 233-250. http://doi.org/10.1111/j.0013-2004.2004.00017.x 
Burn, K., Hagger, H., Mutton, T., \& Everton, T. (2003). The complex development of studentteachers' thinking. Teachers and Teaching: Theory and Practice, 9(4), 309-331.

Carr, D. (2006). Professional and Personal Values and Virtues in Education and Teaching. Oxford Review of Education, 32(2), 171-183.

Cesarani, D. (2016). Final solution: the fate of the Jews 1933-49. London: Macmillan.

Ciampa, K., \& Gallagher, T. L. (2016). Teacher collaborative inquiry in the context of literacy education: examining the effects on teacher self-efficacy, instructional and assessment $\begin{array}{llll}\text { practices. Teachers } \quad \text { and } & \text { 858-878. }\end{array}$ http://doi.org/10.1080/13540602.2016.1185821

Counsell, C. (2000). Historical knowledge and historical skills: A distracting dichotomy. In J. A. \& R. Phillips (Ed.), Issues in History Teaching (pp. 54-71). Routledge.

Counsell, C. (2008). Teaching about historical change and continuity. In Schools History Project.

De Neve, D., \& Devos, G. (2016). How do professional learning communities aid and hamper professional learning of beginning teachers related to differentiated instruction? Teachers and Teaching, 1-22. http://doi.org/10.1080/13540602.2016.1206524

Donaldson, G. (2015). Successful Futures: Independent Review of Curriculum and Assessment Arrangements in Wales. Retrieved from https://hwbplus.wales.gov.uk/schools/6714052/Documents/Donaldson Report.pdf

Flyvbjerg, B. (2001). Making social science matter: why social inquiry fails and how it can succeed again. Cambridge: Cambridge University Press.

Foster, S., Pettigrew, A., Pearce, A., Hale, R., Burgess, A., Salmons, P., \& Lenga, R. (2016). What do students know and understand about the Holocaust? Evidence from English secondary schools. Centre for Holocaust Education. Centre for Holocaust Education, Institute of Education, University College London.

Hattie, J. (2012). Visible learning for teachers [electronic resource] : maximizing impact on learning. London : Routledge.

Lunenberg, M., \& Korthagen, F. (2009). Experience, Theory, and Practical Wisdom in Teaching and Teacher Education. Teachers and Teaching: Theory and Practice, 15(2), 225-240. http://doi.org/10.1080/13540600902875316

McIntyre, D. (1993). Theory, Theorizing and Reflect ion in Initial Teacher Education. In . \& J. Gates, P \& Calderhead (Eds.), Conceptualising Reflection in Teacher Development (pp. 3952). Falmer.

Priestley, M., Edwards, R., Priestley, A., \& Miller, K. (2012). Teacher Agency in Curriculum Making: Agents of Change and Spaces for Manoeuvre. Curriculum Inquiry, 42(2), 191-214. http://doi.org/10.1111/j.1467-873X.2012.00588.x

Reynolds, D. (2013). The long shadow: the Great War and the twentieth century. London : Simon \& Schuster.

Runte, R. (1998). The Impact of Centralized Examinations on Teacher Professionalism. Canadian Journal of Education, 23(2), 166-181. 
Sachs, J. (2016). Teacher professionalism: why are we still talking about it? Teachers and Teaching, 22(4), 413-425. http://doi.org/10.1080/13540602.2015.1082732

SHP. (n.d.). Schools History Project principles. Retrieved October 19, 2016, from http://www.schoolshistoryproject.co.uk/about-shp/principles/

Stotesbury and Dorling. (2015). Understanding Income Inequality and its Implications: Why Better Statistics are Needed. Retrieved from http://www.dannydorling.org/?page_id=4984

Thompson, I. (2014). Communication, Culture and Conceptual learning: Task Design in the English classroom. In I. Thompson (Ed.), Designing Tasks in Secondary Education: Enhancing subject understanding and student engagement. (pp. 86-106). New York : Routledge.

Todd, J. (2014). Negotiating knowledge in the history classroom. In Designing Tasks in Secondary Education: Enhancing subject understanding and student engagement. (pp. 152-170). Routledge/Taylor \& Francis Group.

Wineburg, S. S., \& Wilson, S. M. (1991). Models of Wisdom in the Teaching of History. History Teacher, 24(4), 395-412. 